\title{
Performance of supplemented heifers on Marandu grass pastures in the wet-to-dry transition and dry seasons
}

\section{Amanda Prates Oliveira ${ }^{1}$, Liandra Maria Abaker Bertipaglia², Gabriel Mauricio Peruca de Melo², Telma Teresinha Berchielli ${ }^{1}$, Ana Cláudia Ruggieri ${ }^{1}$, Daniel Rume Casagrande ${ }^{3}$, Ricardo Andrade Reis ${ }^{1}$}

\author{
${ }^{1}$ Faculdade de Ciências Agrárias e Veterinárias de Jaboticabal - FCAVIUNESP. \\ 2 UNICASTELO/Descalvado. \\ ${ }^{3}$ Universidade Federal de Lavras - DZO/UFLA.
}

\begin{abstract}
The objective of the present study was to evaluate the characteristics of the sward canopy of Marandu grass during the rainy season, the wet-to-dry transition and the dry seasons, between March and September 2004, under intermittent grazing, and to correlate those characteristics with the performance of crossbred heifers receiving mineral supplements ad libitum or protein supplements. The experiment consisted of a randomized block design with three blocks (set of 13 paddocks), each containing five crossbred heifers per experimental unit, totaling 15 replicates. The heifers were given protein supplements daily in individual stalls and received an average $4 \mathrm{~g} / \mathrm{kg} /$ day of the supplement during the rainy season and $5 \mathrm{~g} / \mathrm{kg} /$ day during the dry season. Their weight gain was assessed monthly. The pasture structure was assessed through destructive sampling, and the bromatological composition of esophageal extrusa samples was also assessed. Analysis of variance was used to assess performance, and regression analysis was used to evaluate the sward canopy characteristics in relation to the months of the year. A cluster procedure was used to determine the similarity between the months of the year under assessment. Two different groups were formed for pasture evaluation: one group including the months of March to July and another group including the months of August and September. The first group exhibited a better canopy structure than the second group. This fact was corroborated by the animal performance, which was lower during the months of the second group. Low-intake protein supplementation was effective in increasing the performance of the grazing heifers. Pasture structure is critical for animal performance in a grazing environment, regardless of the type of supplementation.
\end{abstract}

Key Words: nutritional value, pasture management, supplement, tropical grass, weight gain

\section{Introduction}

The beef cattle industry has undergone major changes with the globalization of the economy. The increased competition in the market has obliged farms to grow into companies and to develop efficient activities from a productive and economic point of view. This scenario has led to the search for technologies that improve the use of pastures, increase animal performance and reduce the age of slaughter or age at first calving, thus enabling the farm to have a greater productive efficiency.

One widely explored technique is the use of supplements for grazing animals, which allows the producer to choose weight maintenance throughout the dry season or weight gains of approximately $1.0 \mathrm{~kg} /$ day, according to the type and amount of supplement provided (Paulino et al., 2003). However, the response to supplementation depends on the forage allowance, which, in a grazing environment, can be related to the nutritional value and the structure of the sward canopy (Reis et al., 2006). In this sense, seasonal changes greatly influence the quality of the forage available in a pasture and, consequently, the effect of supplementation. Recent studies have shown this effect during the wet-todry season transition both on feeding behavior and animal performance (Casagrande et al., 2011; Moretti et al., 2011). Therefore, the characterization of the canopy during the rainy season, the wet-to-dry transition and the dry seasons, combined with supplementation, is essential to define management strategies to shorten the beef cattle cycle.

Given the above, the objective of the present study was to evaluate the characteristics of the sward canopy of Marandu grass during the rainy season, the wet-todry transition and the dry seasons, under intermittent grazing, and to correlate those characteristics to the performance of crossbred heifers receiving mineral or protein supplements. 


\section{Material and Methods}

The experiment was conducted between January and September 2004 at the experimental sector of Forage Production of the Departamento de Zootecnia, Faculdade de Ciências Agrárias e Veterinárias/Universidade Estadual Paulista (FCAV/UNESP), Jaboticabal, São Paulo (SP, Brazil), located at latitude $21^{\circ} 15^{\prime} 22^{\prime \prime}$ South, longitude $48^{\circ} 18^{\prime} 58^{\prime \prime}$ West and an altitude of $595 \mathrm{~m}$. The experiment used a pasture of Brachiaria brizantha (Hochst ex A. Rich) Stapf cv Marandu, established in 2001 on a Red Latosol (Santos et al., 2006). At the beginning of the experiment, the soil presented the following chemical characteristics: $\mathrm{pH} 5.1 ; 24 \mathrm{~g} / \mathrm{dm}^{3}$ organic matter $(\mathrm{OM}) ; 10 \mathrm{mg} / \mathrm{dm}^{3} \mathrm{P}$; $1.8 \mathrm{mmol}_{\mathrm{c}} / \mathrm{dm}^{3} \mathrm{~K} ; 18 \mathrm{mmol} / \mathrm{dm}^{3} \mathrm{Ca}^{2+} ; 11 \mathrm{mmol} / \mathrm{dm}^{3}$ $\mathrm{Mg}^{2+} ; 25 \mathrm{mmol}_{\mathrm{c}} / \mathrm{dm}^{3} \mathrm{H}+\mathrm{Al}$; and $55 \%$ base saturation (V\%). Maintenance fertilization consisted of $150 \mathrm{~kg} / \mathrm{ha} \mathrm{N}$, which was fractionated after each grazing cycle during the rainy season. The climate in Jaboticabal is subtropical (Cwa), according to the Köppen classification, with rainy summers and dry winters. Precipitation and temperature data obtained throughout the study were extracted from a set of data belonging to a collection from the Agrometeorology Group, Department of Exact Sciences, located 800 meters from the experimental area (Table 1).

The experimental treatments consisted of two types of supplementation, i.e., mineral and protein supplements, both commercially available products for the rearing of beef animals (Table 2). A randomized block design was used with repeated measures in time, corresponding to the months of March to September 2004. The 19.5 ha experimental area was divided into 39 plots, and a set of 13 plots was considered one block. In total, there were three blocks with five replicates each (animals), all randomly assigned.

Table 1 - Absolute daily maximum, minimum, and average temperature and average monthly precipitation values observed during the period from January to October 2004

\begin{tabular}{lcccc}
\hline \multirow{2}{*}{ Month } & \multicolumn{3}{c}{ Temperature $\left({ }^{\circ} \mathrm{C}\right)$} & $\begin{array}{c}\text { Precipitation } \\
(\mathrm{mm})\end{array}$ \\
\cline { 2 - 4 } January & 33.1 & 17.1 & 23.9 & 101.0 \\
February & 33.4 & 16.4 & 23.7 & 97.3 \\
March & 33.8 & 14.2 & 23.4 & 25.6 \\
April & 32.6 & 12.2 & 22.8 & 41.2 \\
May & 31.3 & 7.4 & 18.7 & 39.3 \\
June & 27.8 & 6.6 & 18.1 & 17.2 \\
July & 30.5 & 6.4 & 17.8 & 22.0 \\
August & 34.4 & 8.3 & 20.5 & 0.0 \\
September & 37.5 & 15.2 & 25.0 & 21.2 \\
October & 36.3 & 10.6 & 24.3 & 48.6 \\
\hline
\end{tabular}

Five animals per treatment (mineral and protein supplements) were assigned to each block, and additional animals were used as needed to obtain the necessary stocking rate, with a total of 30 experimental animals (testers), consisting of F1 heifers (Santa Gertrudes $\times$ Brahman) that were approximately seven months of age with an average body weight of $200 \mathrm{~kg}$. These animals were selected from a total of 90 animals of the same age and breed, according to the criteria of docility, weight uniformity and response to daily handling during the period of adaptation, which was conducted between December 2003 and February 2004. The 60 remaining animals were used to control the stocking rate, whenever necessary. The selected animals were then randomly assigned to treatments, identified with ear tags and treated for endo- and ectoparasites.

The experimental period was initiated after the adaptation period, which occurred in January and February 2004, with monthly evaluations from March to September 2004. An intermittent stocking grazing method was used throughout the experiment. An average occupation period of three days with 39 days of rest and a stocking rate of 5.3 AU/ha were used during the rainy season, whereas an average occupation period of two days with 24 days of rest and a stocking rate of $2.5 \mathrm{AU} / \mathrm{ha}$ were used for the dry season. The days of occupation and rest varied throughout the experiment according to herbage mass. Therefore, the pastures were managed throughout the experimental period so that the total herbage mass would not be lower than $2,500 \mathrm{~kg} / \mathrm{ha}$, as recommended by Euclides et al. (1998). When the minimum forage mass was observed in a paddock belonging to one of the blocks, the animals were moved to the subsequent paddock in all of the blocks.

Because animals from different treatments grazed simultaneously on the same plot, to control the supplement intake of each animal, the heifers were taken to individual $8 \mathrm{~m}^{2}$ stalls every day at 9 am and supplemented individually. After each heifer was accommodated in its stall, the supplement

Table 2 - Percentage composition of ingredients and guarantee levels of protein and mineral of the supplements used in the rainy and dry seasons

\begin{tabular}{|c|c|c|c|c|}
\hline \multirow{3}{*}{ Ingredients } & \multicolumn{2}{|c|}{ Protein supplement } & \multicolumn{2}{|c|}{ Mineral supplement } \\
\hline & \multicolumn{4}{|c|}{ Period } \\
\hline & Dry & Rainy/dry & Dry & Rainy/dry \\
\hline Citrus pulp $(\mathrm{g} / \mathrm{kg})$ & 200 & 570 & - & - \\
\hline Cottonseed meal $(\mathrm{g} / \mathrm{kg})$ & 460 & 320 & - & - \\
\hline Urea 46\% (g/kg) & 30 & 30 & - & - \\
\hline Soybean hulls ( $\mathrm{g} / \mathrm{kg}$ ) & 200 & 30 & - & - \\
\hline Minerals (g/kg) & 110 & 50 & 1000 & 1000 \\
\hline Crude protein $(\mathrm{g} / \mathrm{kg}$ DM) & 300 & 500 & 0 & 0 \\
\hline
\end{tabular}


was provided according to the supplementation criterion of each animal. The animals remained in the stalls until $13 \mathrm{~h} 00$ and were then taken to the respective paddock. The protein supplement was provided at $4 \mathrm{~g} / \mathrm{kg}$ body weight (BW)/day during the rainy season and $5 \mathrm{~g} / \mathrm{kg} \mathrm{BW} /$ day during the dry season. The time for supplementation was selected so that the animals would remain in the stalls during the warmer periods and times of lower grazing activity (after peak grazing in the morning), seeking to minimize the effects of grazing behavior. The remaining supplements were collected daily, weighed after the animals were released into the pasture and considered as surplus when their weight was equal to or greater than $50 \mathrm{~g} / \mathrm{kg}$ of the weight provided. Subsamples of the supplement were obtained to determine the dry matter content at $105^{\circ} \mathrm{C}$ using the method described by the Association of Analytical Communities (AOAC, 1990).

To determine their performance, the animals were weighed at the beginning of the experiment and every 28 days thereafter, and each weighing occurred following a 15-hour fast from feed and water. Herbage mass was sampled monthly, on the first and last day of grazing, in one paddock from each experimental block, which was considered representative of the experimental area. For the herbage mass assessment, the height of the canopy was initially measured using 30 readings per plot, which were obtained at random using a centimeter ruler with a rising plate meter. Once the average height of the sward canopy was determined, four points representative of the condition of the canopy were identified per plot, and cuts were made at each point using metal squares $(0.5 \times 0.5 \mathrm{~m})$. All of the material contained in the square was cut at $15 \mathrm{~cm}$ from the ground, as described by McMeniman (1997). These samples were then taken to the laboratory, where they were weighed and homogenized, and two subsamples were obtained from each sample. The first subsample was divided into leaf, stem and sheath and dead material, and the second subsample consisted of whole plants. Both subsamples were weighed and placed in a forced air circulation oven at $55{ }^{\circ} \mathrm{C}$ for 72 hours and then weighed again. The proportion of each component was used to estimate the leaf:stem and green: dead material ratios as well as the green herbage mass.

Esophageal extrusa samples were collected according to the method proposed by McMeniman (1997), with an esophageal fistulated animal. A crossbred, castrated animal, aged 36 months, with an average weight of $400 \mathrm{~kg}$, was used for sampling. Screen-bottomed fabric collection bags were attached to the animal to drain excess saliva. The animal fasted from feed for approximately 12 hours on the day before sample collection. Sample collection occurred every 28 days. On the day of sampling, the esophageal tube was removed, and the collection bag was positioned. The animal was monitored for 20 minutes, with no interference in grazing behavior. The bag was then removed, and the extrusa sample was homogenized and dried in an oven at $55^{\circ} \mathrm{C}$ until a constant weight was achieved. After predrying, the samples were ground in a Wiley mill using a $1 \mathrm{~mm}$ sieve. The amounts of neutral detergent fiber-bound nitrogen (NDF-N) $\left(\mathrm{B}_{3}\right)$ and acid-detergent fiber-bound nitrogen (ADF-N) (C) were subsequently determined through the system proposed by the Cornell Net Carbohydrate and Protein System (CNCPS), according to Sniffen et al. (1992). The crude protein content was also determined (Silva \& Queiroz, 2002). The levels of neutral detergent fiber (NDF), acid detergent fiber (ADF), hemicellulose, cellulose and lignin were also assessed according to the method described by Silva \& Queiroz (2002). The in vitro dry matter digestibility (IVDMD) was determined using the method described by Tilley \& Terry (1963), according to Silva \& Queiroz (2002).

The data for animal performance were analyzed according to the randomized block design, with three blocks and five replicates each, totaling 15 replicates in a split-plot design, where the effect of supplementation was assessed in the plot and the effect of the months was assessed in the subplot. The data were initially analyzed regarding the normality of error, and outliers were excluded. Analysis of variance was then performed using procedure PROC GLM of software SAS (Statistical Analysis System, version 9.2).

Data referring to the quantitative and qualitative characteristics of the pasture were analyzed in three replicates according to the randomized block design by regression analysis using PROC REG of the SAS system in relation to the sampled months of March to September, which were identified as months 3 to 9, respectively. Furthermore, the data were analyzed based on averages obtained for the variables and cluster analysis using the cluster procedure to determine the similarity between the months under assessment, considering the objectives and quantitative and qualitative parameters separately as variables of interest for the similarity criteria.

\section{Results and Discussion}

The height of the canopy at the time of the entry and exit of animals into and from the paddocks was adjusted to a quadratic model $(\mathrm{P}<0.05)$ in relation to the evaluated months (Table 3).

Pre-grazing height of the canopy was greater than $35 \mathrm{~cm}$ in the first four months of the study, from March 
to June. The post-grazing height was always greater than $25 \mathrm{~cm}$. The pasture structure allowed the animals to explore approximately $10 \mathrm{~cm}$, corresponding to $25 \%$ of the pre-grazing height. From August onwards, the proportion of the explored height was approximately $20 \%$ of the pregrazing height. The animals entered at a pre-grazing height of $23 \mathrm{~cm}$ and left when the pasture was approximately $18 \mathrm{~cm}$ high, so the explored extract was less than $5 \mathrm{~cm}$.

The pre- and post-grazing totals and the green herbage masses were also adjusted to a quadratic model $(\mathrm{P}<0.05)$. The largest herbage masses were observed in the months of March to June, the period in which the total herbage mass was always greater than $13,000 \mathrm{~kg} / \mathrm{ha}$, and the green herbage mass was greater than $6,000 \mathrm{~kg} / \mathrm{ha}$. The smallest herbage mass, either green or dead, was observed in September. In addition to the quantitative restriction of forage at the end of the experiment, the ratio between the green and dead herbage masses was also reduced, indicating a worsening of the sward canopy structure in August and particularly in September. The percentage of green material in relation to the pre-grazing total herbage mass was greater than $50 \%$ until June, when the largest proportion of total herbage mass became dead material. This proportion increased dramatically until the end of the experimental period (Table 3). Tendencies similar to those observed for the pregrazing period regarding the proportion of green and dead material were noted in the post-grazing period. However, the proportion of dead material was always greater than the green material during pre-grazing, which can be explained by the preference of the animal for green forage over dead forage (Ruggieri et al., 2008).

These results show that the structure of the canopy deteriorated at the end of the experimental period. This fact reflects the climatic conditions of the months of June, July and August, when the minimum temperature was below
$10{ }^{\circ} \mathrm{C}$ and precipitation was negligible (Table 1). It is worth mentioning that during the summer, grasses of the genus Brachiaria grow continuously with a high potential for green mass production (Lara \& Pedreira, 2011). However, in the winter, or the dry season, vegetative growth is reduced and the reproductive phase accelerates due to the decrease in photoperiod, the drop in temperature and inadequate rainfall conditions, all of which also initiate the process of leaf senescence.

Were observed shows the existence of two large groups of months in relation to canopy structure, one including the months of August and September and the other including the months of March, April, May, June and July. The latter is subdivided into two subgroups, one including the month of July and another including the remaining months (Figure 1). This result is confirmed by principal component analysis (Figure 2), which shows the fractions of the pasture that were changed throughout the experiment.

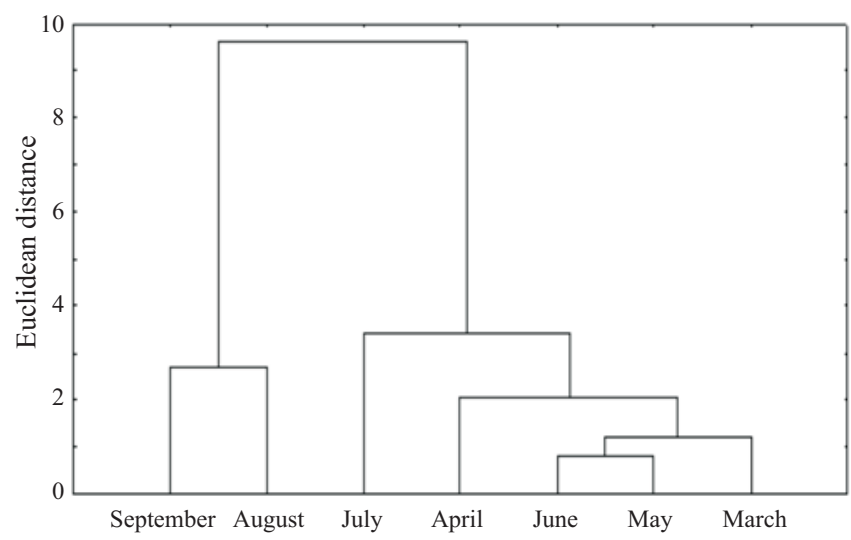

Figure 1 - Dendrogram of the Cluster analysis performed for pool of months, using the quantitative variables obtained in the beginning of the grazing period.

Table 3 - Equations of the variables of the palisade grass pasture structure in relation to the months from March to September

\begin{tabular}{|c|c|c|c|}
\hline Variable & Equation $^{1}$ & $\mathrm{CV}, \%$ & $\mathrm{R}^{2}$ \\
\hline Height (pre-grazing) & $y=42.9881+2.3131 x-0.5036 x^{2}$ & 13.57 & 0.7339 \\
\hline Height (post-grazing) & $\mathrm{y}=44.8056-2.6988 \mathrm{x}-0.0234 \mathrm{x}^{2}$ & 7.24 & 0.9117 \\
\hline THM (pre-grazing) & $\mathrm{y}=8229.1143+2951.1286 \mathrm{x}-350.2286 \mathrm{x}^{2}$ & 13.87 & 0.7673 \\
\hline THM (post-grazing) & $\mathrm{y}=7455.8333+1191.3071 \mathrm{x}-158.0904 \mathrm{x}^{2}$ & 11.91 & 0.7333 \\
\hline GHM (pre-grazing) & $\mathrm{y}=3223.9500+2114.1059-257.9059 \mathrm{x}^{2}$ & 12.29 & 0.9198 \\
\hline GHM (post-grazing) & $y=2316.7769+1066.7297 x-135.6465 x^{2}$ & 20.06 & 0.7984 \\
\hline$\%$ GHM (pre-grazing) & $y=37.4246+10.7226 x-1.1163 x^{2}$ & 3.23 & 0.9373 \\
\hline \% GHM (post-grazing) & $\mathrm{y}=38.2008+7.9417 \mathrm{x}-0.8519 \mathrm{x}^{2}$ & 8.78 & 0.6253 \\
\hline$\%$ DMM (pre-grazing) & $y=62.5436-10.6917 x+1.1123 x^{2}$ & 4.31 & 0.9362 \\
\hline \% DMM (post-grazing) & $y=61.4619-7.7976 x+0.8381 x^{2}$ & 9.43 & 0.6197 \\
\hline \% Leaf (pre-grazing) & $\mathrm{y}=39.2976+1.3893 \mathrm{x}-0.1631 \mathrm{x}^{2}$ & 4.51 & 0.3534 \\
\hline$\%$ Leaf (post-grazing & $y=11.7302+9.4714 x-0.7825 x^{2}$ & 11.87 & 0.3056 \\
\hline$\%$ Stem (pre-grazing) & $y=60.7032-1.3905 x+0.1635 x^{2}$ & 3.17 & 0.3526 \\
\hline$\%$ Stem (post-grazing) & $\mathrm{y}=63.6373-1.9488 \mathrm{x}+0.2377 \mathrm{x}^{2}$ & 5.57 & 0.2816 \\
\hline
\end{tabular}

${ }^{1} \mathrm{P}<0.05$.

THM - total herbage mass; GHM - green herbage mass; DMM - dead material mass; CV - coefficient of variation. 


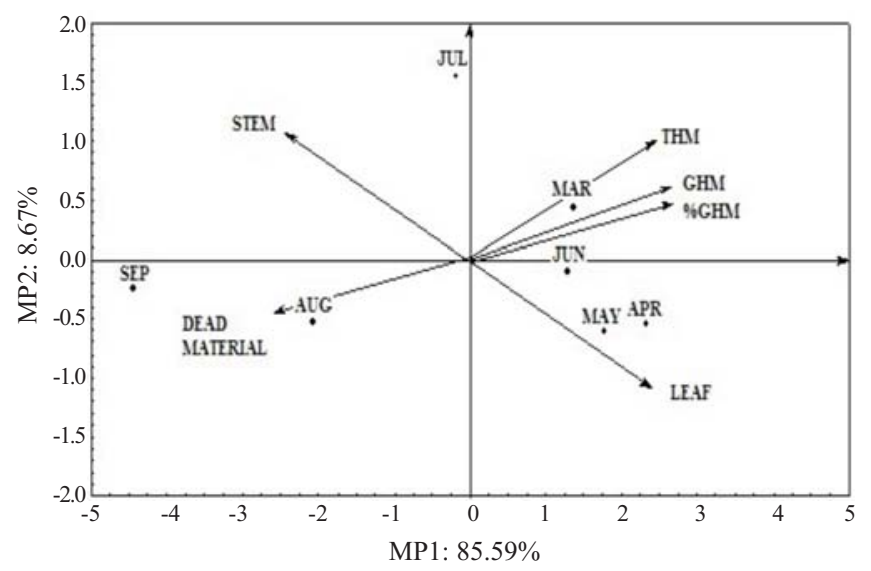

THM - total herbage mass; GHM - green herbage mass.

Figure 2 - Main components and distribution of the months among them in terms of quantitative variables obtained during the experimental period.

As previously discussed, a better canopy structure, in relation to total and green herbage mass and the relationship between the green:dead material and leaf: stem ratios, was observed in the months of March, April, May and June, whereas August and September showed the worst canopy structures and July was characterized as an intermediate period.

The fractions of nitrogen compounds in the esophageal extrusa and the fiber fractions, with the exception of lignin, were adjusted to a quadratic model $(\mathrm{P}<0.05)$ in relation to the evaluated months (Table 4). However, low coefficients of determination were recorded, indicating that other factors influenced the behavior of these variables.

Overall, the forage collected during the months of higher plant growth, corresponding to March through July, had a higher cell wall content compared with the forage harvested in August and September, despite the large amount of green material (Table 3).

This response profile in the extrusa samples is due to several factors, including the variation in climatic conditions throughout the seasons of the year, which promote major changes in plant metabolism. An increase in the proportion of reproductive tillers to the detriment of vegetative tillers can often be noted in late summer and early fall due to the reduction in photoperiod (Calvano et al., 2011). Intense aerial tillering, in the shape of rosettes, occurs when these tillers are decapitated through grazing. These aerial tillers, although numerous, are characterized by their reduced size, resulting in little forage accumulation with low structural content (cell wall). Grazing animals are highly selective and tend to choose diets with high percentages of leaves, mainly when the forage contains a high proportion of stem and dead material. Therefore, from March to June, the animals selected leaves that were derived from basal tillers, which are larger in size and have a higher cell wall content, whereas in July and particularly in August and September, the grazing animals selected the green fraction of the forage, which was then composed of aerial tillers in the shape of rosettes, presenting a lower fiber content. Given the selectivity of grazing, the animals tend to seek this type of tiller, and the nutritional value of the diet was therefore high despite the smaller forage mass in the months of August and September. However, the low quantity and structure of this type of forage likely hindered the formation of bites, consequently restricting dry matter intake due to non-nutritional factors (Poppi et al., 1997), which was reflected in the performance of the animals (Table 5).

The crude protein content of the esophageal extrusa was higher in the months of March through June and decreased in the subsequent months (Table 4); however, even in the most critical months, the values of crude protein in the dry matter were above the minimum of $8 \%$ required for rumen function (Detmann et al., 2009). Therefore, the protein content of the forage does not appear to have limited the animal performance in the present study. However, variations in the fractions B3 and $\mathrm{C}$, which are slowly degraded in the rumen or non-degradable, respectively, should be considered. Therefore, the larger these fractions

Table 4 - Equations of the extrusa chemical composition variable according to the months from March to September

\begin{tabular}{|c|c|c|c|}
\hline Variable & Equation $^{1}$ & $\mathrm{CV}, \%$ & $\mathrm{R}^{2}$ \\
\hline \multicolumn{4}{|c|}{ Fiber fractions } \\
\hline Neutral detergent fiber (\% DM) & $\mathrm{y}=73.2944-0.5155 \mathrm{x}-0.0409 \mathrm{x}^{2}$ & 3.29 & 0.4831 \\
\hline Acid detergent fiber (\% DM) & $y=32.6341+3.4107 x-0.3519 x^{2}$ & 4.83 & 0.5759 \\
\hline Cellulose (\% DM) & $y=34.9357-3.9083 x+0.2869 x^{2}$ & 7.54 & 0.4188 \\
\hline Hemicellulose (\% DM) & $y=40.7063-3.9452 x+0.3127 x^{2}$ & 6.93 & 0.2685 \\
\hline \multicolumn{4}{|c|}{ Nitrogen fractions } \\
\hline Crude protein $(\% \mathrm{DM})$ & $\mathrm{y}=6.2825+1.8952 \mathrm{x}-0.1873 \mathrm{x}^{2}$ & 33.95 & 0.0825 \\
\hline $\mathrm{B} 3$ fraction $(\%$ Total $\mathrm{N})$ & $y=-6.6298+18.656 x-1.7399 x^{2}$ & 12.66 & 0.5964 \\
\hline $\mathrm{C}$ fraction $(\%$ Total $\mathrm{N})$ & $\mathrm{y}=2.7159+4.0571 \mathrm{x}-0.2635 \mathrm{x}^{2}$ & 22.35 & 0.2569 \\
\hline
\end{tabular}

${ }^{1} \mathrm{P}<0.05$.

$\mathrm{CV}$ - coefficient of variation; DM - dry matter. 
are, the lower the amount of nitrogen available to the microorganisms in the rumen. The B3 crude protein fraction was adjusted to a quadratic model, increasing its content until July, and the lowest values of the B3 fraction were observed in August and September (Table 4). This can be explained by the same reasons explained above regarding the behavior of the fiber fraction. The lowest values of fraction $\mathrm{C}$, expressed as a percentage of crude protein, were noted in the months of April and May. A deeper knowledge of protein fractionation in forage plants is necessary for the formulation of specific supplements for each season.

The dendrogram resulting from the cluster analysis using the qualitative variables obtained during the experimental period shows the existence of two large groups, which is similar to the results obtained for the quantitative variables, where one group is composed of the months of August and September and the other group consists of the months of March, April, May, June and July (Figure 3).

This structure is confirmed by the principal component analysis (Figure 4). By correlating this cluster with the average data of the variables used, it is possible to propose, as the main interpretation, that the months of August and September were grouped due to the higher lignin and IVDMD contents and the lower fraction $\mathrm{C}$ levels. Conversely, it can be noted that the other group was composed of the months of April, May, June and July. In this group, the determinant variables were mainly the high levels of B3, crude protein and cellulose.

The animals from both treatments presented a lower average daily weight gain during the months of August and September compared with the period from April to June. This response was a consequence of the variations in quantity and quality of the available forage. As previously

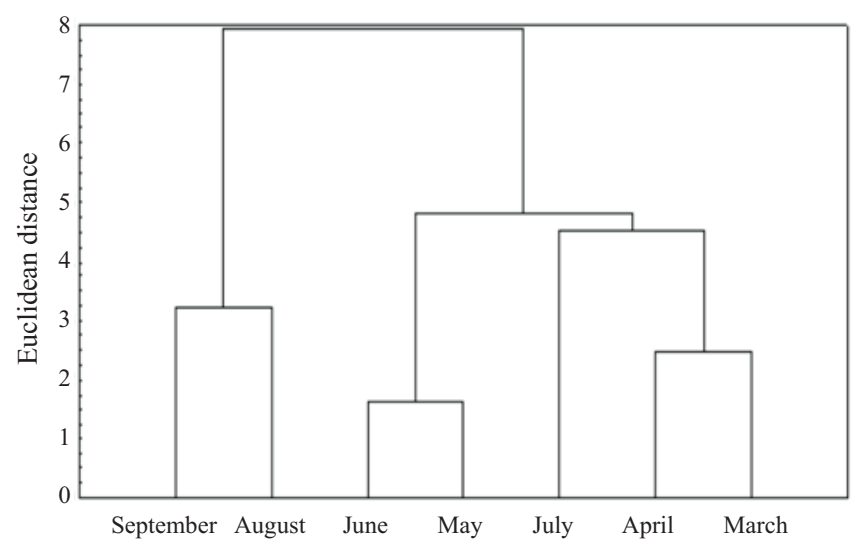

Figure 3 - Dendrogram of the Cluster analysis performed for pool of months, using the qualitative variables obtained in the beginning of the grazing period. discussed, the cluster analysis divided both parameters into two periods: March to July and August to September. The second group was characterized by the worst pasture structure and the lowest forage nutritional value. The poor performance of the animals during this period can therefore be explained, indicating that August and September are the most critical months in grazing systems.

The animals receiving protein supplements showed higher gains in the periods of April through June and August through September compared with those receiving mineral supplements (Table 5). However, the difference in weight gain between the two groups was not significant in the months of March and July ( $P>0.05)$. In March, this fact can be explained by irregular intake of the supplement and stress during the period of adaptation to management at the beginning of the experiment. However, after this period, the animals demonstrated regular intake of the protein supplement, indicating that they had been conditioned to daily management (Table 5).

The lowest green herbage masses were observed in August and September: 2,887 and 1,495 kg/ha of green dry herbage mass (GDM), respectively, associated with low values of protein (CP, 6.25\%) and high levels of fraction $\mathrm{C}$ (22.17\% of CP) in August. Although the stocking rate had been reduced (Table 5), the combination of the quantitative and qualitative factors of the forage resulted in decreased weight gain of the individual animals.

Regarding the animals supplemented with low-intake protein supplements, the provision of 4 and $5 \mathrm{~g} / \mathrm{kg} \mathrm{BW}$ in the rainy and dry seasons, respectively, led to high gains, considering the amount of supplement consumed (Table 5).

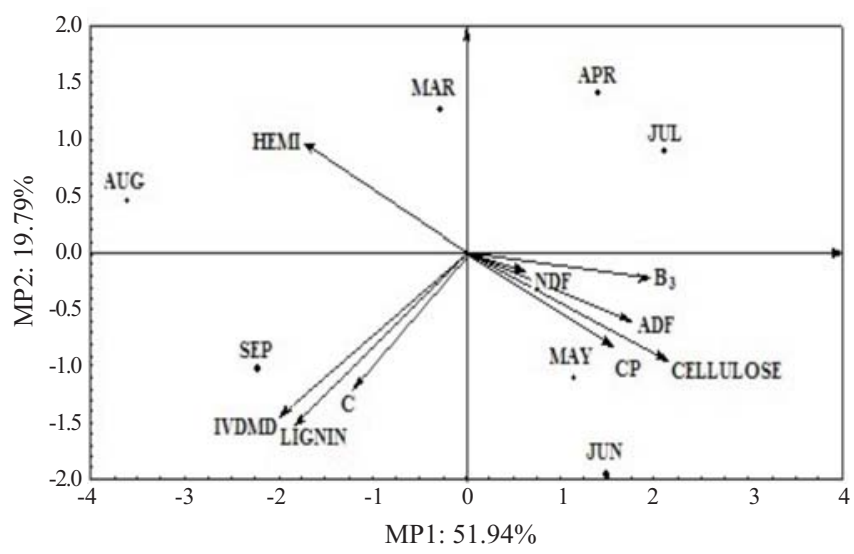

HEMI - hemicellulose; NDF - neutral detergent fiber; ADF - acid detergent fiber; $\mathrm{CP}$ - crude protein; IVDMD - in vitro dry matter digestibility.

Figure 4 - Main components and distribution of the months among them in terms of qualitative variables obtained during the experimental period.

R. Bras. Zootec., v.41, n.10, p.2255-2262, 2012 
Table 5 - Performance of heifers receiving mineral or protein supplement and characteristics of the Brachiaria brizantha pasture managed under a rotational grazing system

\begin{tabular}{|c|c|c|c|c|c|c|c|}
\hline \multirow{2}{*}{ Supplement } & \multicolumn{7}{|c|}{ Month } \\
\hline & March & April & May & June & July & August & September \\
\hline & \multicolumn{7}{|c|}{ Weight gain (kg/day) } \\
\hline Mineral (MS) & $0.254 \mathrm{a}$ & $0.492 b$ & $0.270 \mathrm{~b}$ & $0.294 b$ & $0.429 \mathrm{a}$ & $0.230 \mathrm{~b}$ & $-0.063 b$ \\
\hline Protein supplement (PS) & $0.294 \mathrm{a}$ & $0.714 \mathrm{a}$ & $0.492 \mathrm{a}$ & $0.405 \mathrm{a}$ & $0.444 \mathrm{a}$ & $0.437 \mathrm{a}$ & $0.230 \mathrm{a}$ \\
\hline $\mathrm{CV}(\%)$ & 21.71 & 26.03 & 21.01 & 30.01 & 18.56 & 20.50 & 78.49 \\
\hline PS intake (g/animal/day) & 0.750 & 0.860 & 0.850 & 1.290 & 1.050 & 1.400 & 1.270 \\
\hline Body weight MS (kg) & 226 & 233 & 250 & 256 & 265 & 276 & 279 \\
\hline Body weight PS (kg) & 233 & 241 & 260 & 273 & 282 & 296 & 301 \\
\hline Total forage allowance $(\mathrm{kg} / 100 \mathrm{~kg} \mathrm{BW} /$ day $)$ & 19.3 & 18,1 & 24.0 & 24.6 & 26.4 & 27.9 & 17.2 \\
\hline Green forage allowance $(\mathrm{kg} / 100 \mathrm{~kg} \mathrm{BW} /$ day $)$ & 9.4 & 10.1 & 13.57 & 11.65 & 12.02 & 11.27 & 9.24 \\
\hline Stocking rate (AU/ha) & 5.3 & 5.4 & 2.9 & 3.0 & 3.1 & 2.8 & 2.8 \\
\hline
\end{tabular}

Averages followed by the same lower-case letter in the column of weight gain do not differ by Tukey's test at $5 \%$ probability.

$\mathrm{CV}$ - coefficient of variation; TFA - total forage allowance; GFA - green forage allowance; BW - body weight; AU - animal unit.

This response pattern was also verified by Fernandes et al. (2010), who worked with animals supplemented with $6 \mathrm{~g} / \mathrm{kg} \mathrm{BW}$ during the rainy season, with a stocking rate of $6 \mathrm{AU} / \mathrm{ha}$ and a forage mass of $3,500 \mathrm{~kg} / \mathrm{ha}$ and obtained gains of $0.870 \mathrm{~kg} /$ day. Only the animals receiving mineral supplements had higher gains than those observed in the present study $(0.750 \mathrm{~kg} /$ animal $/$ day $)$, indicating a higher quality of the forage provided in that study.

A fact worth mentioning is that total dry herbage mass was not the parameter that best correlated with the weight gain of the grazing animals. It can be observed that gain is directly related to the supply of green herbage mass (Figure 5).

This observation is consistent with that suggested by Euclides (1995), who claimed that animal intake and production are not usually correlated with the total herbage available but rather with the availability of green dry

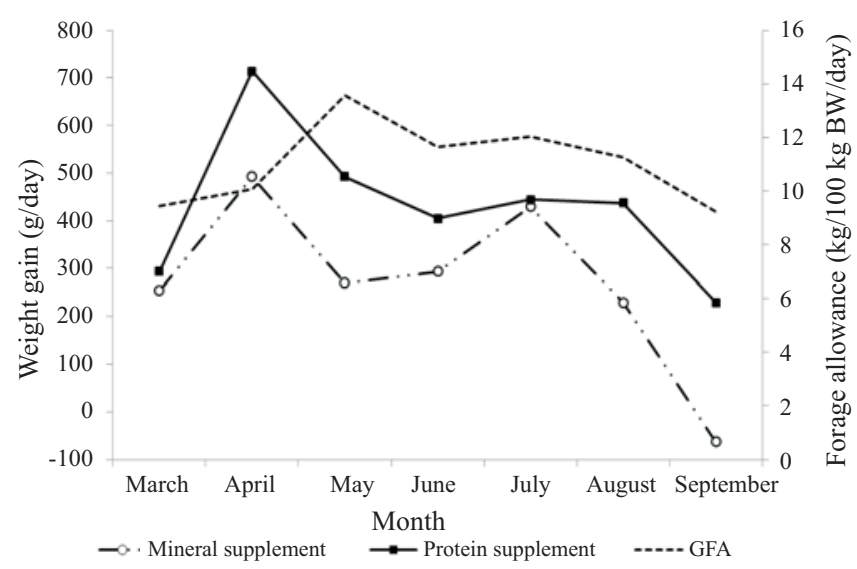

Figure 5 - Green dry matter allowance (GFA) and performance of heifers supplemented with protein or mineral salt maintained on Brachiaria brizantha pasture from March to September. matter. A high supply of green herbage mass was obtained with the type of management adopted in the present study. Forage supply ranged from 15 to $26 \mathrm{~kg} / 100 \mathrm{~kg} \mathrm{BW} /$ day of total herbage mass or 9 to $12 \mathrm{~kg} / 100 \mathrm{~kg} \mathrm{BW} /$ day of green herbage mass from the moment the animals were introduced into the paddock and throughout the experiment (Table 5). However, as previously discussed, the structure of the canopy may have limited forage intake even with the large forage supply, especially in August and September, when the green herbage mass had a high ratio of stem to dead material.

This unfavorable structure increased selectivity by the animals, increasing the intake of smaller tillers (rosettes), thereby generating a diet with lower fiber content, as mentioned above. This greater selectivity likely resulted in the animal spending more time performing the bite as well as the formation of smaller bites due to the unfavorable structure of the canopy, thus compromising the rate of instantaneous intake and possibly the daily forage intake (Hodgson, 1990). This hypothesis was supported by the lower performance of the animals during this period, regardless of the type of supplementation. The canopy structure was the main determinant of animal performance because this structure greatly influences the ingestive behavior of grazing animals (Casagrande et al., 2011) and, consequently, their forage intake.

The stocking rate observed was 5.32 to $2.82 \mathrm{AU} /$ ha in March and September, respectively. From May onwards, the stocking rate was reduced, even though the herbage mass remained high. This decision was made to ensure forage supply throughout the experimental period. The smaller forage supply $(9.24 \mathrm{~kg} / 100 \mathrm{~kg} \mathrm{BW}$ of green herbage mass), along with the smaller herbage mass and worse canopy structure, resulted in a lower weight gain in September, which is considered the most critical month of the dry 
season. Furthermore, the structural characteristics of the pasture promoted unfavorable conditions for forage intake, which can be proven by the smaller mass of leaves and green matter, leading to poor performance. These results are consistent with the assertion by Euclides et al. (2008), who studied three cultivars of Brachiaria brizantha (Piatã, Xaraes and Marandu) and concluded that the structural characteristics were more limiting than the nutritional value in controlling the animal weight gain.

\section{Conclusions}

Low-intake protein supplementation during the wet-todry transition and dry seasons is effective in increasing the performance of grazing heifers. The structure of the pasture is critical to animal performance in a grazing environment, regardless of the type of supplementation.

\section{References}

ASSOCIATION OF OFFICIALANALYTICAL CHEMISTS - AOAC. Official methods of analysis of the Association of Analytical Chemists. 15.ed. Arlington: 1990. 1117p.

CALVANO, M.P.C.A; EUCLIDES, V.P.B.; MONTAGNER, D.B. et al. Tillering and forage accumulation in Marandu grass under different grazing intensities. Revista Ceres, v.58, p.781-789, 2011.

CASAGRANDE, D.C.; AZENHA, M.V.; VALENTEI, A.L.S. et al. Canopy characteristics and behavior of Nellore heifers in Brachiaria brizantha pastures under different grazing heights at a continuous stocking rate. Revista Brasileira de Zootecnia, v.40, p.2294-2301, 2011.

DETMANN, E.; PAULINO, M.F.; MANTOVANI, H.C. et al Parameterization of ruminal fibre degradation in low-quality tropical forage using Michaelis Menten kinetics. Livestock Science, v.126, p.136-146, 2009.

EUCLIDES, V.P.B. Valor alimentício de espécies forrageiras do gênero Panicun. In: SIMPÓSIO SOBRE MANEJO DE PASTAGENS, 12. 1995, Piracicaba. Anais... Piracicaba: FEALQ, 1995. p.245-273.

EUCLIDES, V.P.B.; EUCLIDES FILHO, K.; ARRUDA, Z.J. Desempenho de novilhos em pastagem de Brachiaria decumbens submetidos a diferentes regimes alimentares. Revista Brasileira de Zootecnia, v.27, p.246-254, 1998.

EUCLIDES, V.P.B.; MACEDO, M.C.M.; VALLE, C.B. et al. Produção de forragem em características da estrutura do dossel de cultivares Brachiaria brizantha sob pastejo. Pesquisa Agropecuária Brasileira, v.43, p.1805-1812, 2008.
FERNANDES, L.O.; REIS, R.A.; PAES, J.M.V. Efeito da suplementação no desempenho de bovinos de corte em pastagem de Brachiaria brizantha cv. Marandu. Ciência e Agrotecnologia, v.34, p.240-248, 2010.

HODGSON, J. Grazing management: science into practice. New York: Longman Scientific \& Technical, 1990. 203p.

LARA, M.A.S.; PEDREIRA, C.G.S. Respostas morfogênicas e estruturais de dosséis de espécies de Braquiária à intensidade de desfolhação. Pesquisa Agropecuária Brasileira, v.46, p.760-767, 2011.

McMENIMAN, N.P. Methods of estimating intake of grazing animals. Simpósio sobre tópicos especiais em zootecnia. In: REUNIÃO ANUAL DA SOCIEDADE BRASILEIRA DE ZOOTECNIA, 34 ., 1997, Juiz de Fora. Anais... Juiz de Fora: SBZ, 1997. p.131-168.

MORETTI, M.H.; REIS, R.A.; CASAGRANDE, D.C. et al.. Suplementação protéica energética no desempenho de novilhas em pastejo durante a fase de terminação. Ciência e Agrotecnologia, v.35, p.606-612, 2011.

PAULINO, M.F.; ACEDO, T.S.; SALES, M.F.L. et al. Suplementação como estratégia de manejo das pastagens. In: VOLUMOSOS NA PRODUÇÃO DE RUMINANTES, 1., 2003, Jaboticabal. Anais... Jaboticabal: 2003. p.87-100.

POPPI, D.; McLENNAN, S.R.; BEDIYE, S. et al. Forage quality: Strategies for increasing nutritive value of forages. In. INTERNATIONAL GRASSLAND CONGRESS, 18., 1997, Winnipeg and Saskatoon. Proceedings... Winnipeg and Saskatoon: Canadian Forage Council, Canadian Society of Agronomy, Canadian Society of Animal Science, 1997. p.307-322.

REIS, R.A.; TEIXEIRA, I.A.M.A.; SIQUEIRA, G.R. Impacto da qualidade da forragem na produção animal. In: REUNIÃO ANUAL DA SOCIEDADE BRASILEIRA DE ZOOTECNIA, 43., 2006, João Pessoa. Anais... João Pessoa: SBZ, 2006. (CD-ROM).

RUGGIERI, A.C.; JANUSCKIEWICS, E.R.; CASAGRANDE, D.R. et al. Ingestive behavior of dairy cattle during the different grazing down process of palisadegrass subjected to rotational stocking. In: JOINT ANNUAL ANIMAL SCIENCE MEETING, 2008, Indianapolis. Proceedings... Champaign: American Society of Animal Science, 2008. v.8, p.413.

SANTOS, H.G.; JACOMINE, P.K.T.; ANJOS, L.H.C. et al. Sistema brasileiro de classificação de solos. 2.ed. Rio de Janeiro: Embrapa, 2006. 306p.

SILVA, D.J.; QUEIROZ, A.C. Análise de alimentos: métodos químicos e biológicos. 3.ed. Viçosa, MG: UFV, 2002. 335p.

SNIFFEN, C.J.; O'CONNOR, J.D.; VAN SOEST, P.J. et al. A net carbohydrate and protein system for evaluating cattle diets: II. Carbohydrate and protein availability. Journal of Animal Science, v.70, p.3562-3577, 1992

TILLEY, J.M.A.; TERRY, R.A. A two-stage technique for the in vitro digestion of forage crops. Journal British Grassland Society, v.18, p.104-111, 1963. 